\section{Anthrax outbreak in Soviet Union due to natural causes?}

Washington

AN outbreak of anthrax in the Soviet city of Sverdlovsk nine years ago is still a hot topic for debate. Last week, three Soviet health officials presented evidence at a forum at the US National Academy of Sciences that the anthrax outbreak was caused exclusively by contaminated meat. But the United States continues to insist that the true cause of the epidemic was an explosion at a biological weapons facility near Sverdlovsk that released anthrax spores into the air

The United States has repeatedly pointed to the Sverdlovsk incident as an example of Soviet non-compliance with biological weapons agreements. The Pentagon view is that after spores were released, the Soviet Union attempted to neutralize them by aerial spraying with a hypochlorite solution. There were also a large number of military casualties and heavy military involvement in controlling the incident according to the Pentagon.

But the Soviet health officials presented a very different picture. Before an audience of epidemiologists and other US health researchers gathered at the academy, they attempted to demonstrate that the hypothesis that the Sverdlovsk incident resulted from airborne spores was inconsistent with the facts.

Pyotr Burgasov, former Soviet deputy minister of health, said there were 96 cases of anthrax related to the Sverdlovsk incident. Of these, 17 exhibited the generally non-lethal cutaneous variety, and 79 the more dangerous but rarer gastrointestinal form, of whom 64 died.

Burgasov was among the first health officials on the scene after the outbreak occurred. He said there were no military involved in controlling the epidemic, no aerial spraying for decontamination or any other purpose and no evidence for the type of anthrax that would result from the inhalation of airborne spores.

Instead, Burgasov argued the incident

\section{A further LINK}

\section{London}

BIOTRANSFORMATION is to be the sixth area of collaborative research in the UK Department of Trade and Industry's LINK programme (see Nature 331, 473; 1988). At least 15 companies, including many household names, are expected to contribute a total of $£ 2$ million over three years, with matching funds from the department together with the Science and Engineering Research Council. At least seven universities will be involved, with a focus on Kent, Essex and Warwick.

Peter Newmark the incident.

could be explained by consumption of contaminated meat. A combination of high demand for meat and dwindling supplies of animal fodder drove area farmers to make use of bone meal. Anthrax is endemic to the Sverdlovsk area, and Burgasov explained that some of the bone meal may have been contaminated, thus infecting meat supplies. He said Sverdlovsk residents were urged to turn in any meat they had purchased and were storing, and in many cases anthrax spores were isolated from the meat. Burgasov admits that there is a military facility at Sverdlovsk, but said it was not involved in

The Soviet visit was organized by Harvard University biologist Matthew Meselson, who acted as an adviser to the United States government in 1980 when it first sought to determine whether the Sverdlovsk incident could be the result of

\title{
Therapeutic proteins overtake monoclonals
}

\section{Slough}

HALF a kilogram of protein would not feed a multitude but the profits of selling that quantity of some proteins would. While Celltech was feeding a moderate multitude at the opening of its modish new laboratory and office building last week, half a kilogram of a protein of considerable value was being brewed next door in the first production run of Celltech's 2,000-litre fermenter.

Monoclonal antibodies, of which Celltech is a master brewer, can sell for $\$ 1$ million per $\mathrm{kg}$ and the company can now produce $15 \mathrm{~kg}$ per year. But the demand for monoclonals, at least for diagnostic purposes, is less than had been anticipated.

As a consequence they are likely soon to become only a minor component of the

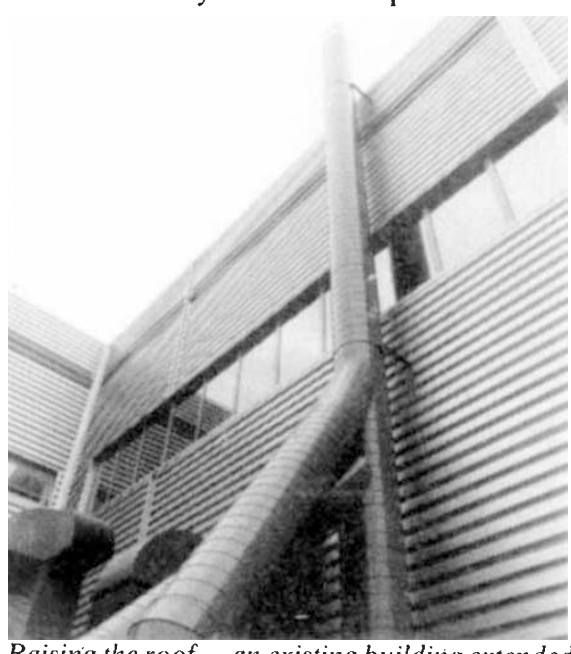
Raising the roof - an existing building extended to accommodate Celltech's new research centre. a biological weapons effort gone awry. At the time, Meselson felt the evidence was equivocal, and he spent the subsequent years trying to find the appropriate Soviet officials who could provide a more complete explanation.

Philip Brachman, an epidemiologist at Emory University and former chief of epidemiology for the Centers for Disease Control (CDC) in Atlanta, agrees that it was difficult to form a conclusion based on evidence available in 1980 . After hearing the explanations provided by Burgasov and his colleagues, Brachman agreed that the anthrax outbreak did not seem to result from an airborne disease, although he pointed out that the Soviets had not presented all their raw data. Alexander Langmuir, also formerly a chief epidemiologist at $\mathrm{CDC}$, went further, saying that the US position needed to be reviewed in the light of the Soviet evidence.

But by the end of last week, the Pentagon had not budged. According to a spokesperson, the Soviet Union "has yet to provide a satisfactory explanation of the event".

Joseph Palca proteins made in Celltech's fermenters. As a sign of the times, the new fermenter's debut was assigned to production of a cellsurface protein, whose further identity was not forthcoming, rather than a monoclonal.

Another sign was the pull-out earlier this year of the Boots Company from Boots-Celltech Diagnostics Ltd, after only two years. One reason for this was last year's loss of $£ 2.45$ million of the joint venture. Nevertheless, claims Celltech's chief operating officer, David Gration, there is no shortage of suitors to take over the stake held by Boots.

The demand for therapeutic proteins is, however, growing. Celltech has already drawn up provisional plans to install a 10,000 litre fermenter. Its construction would be demand-led, say company personnel, hinting that the demand may soon arise from a contract that is under negotiation. Beyond that, sights might be set on a separate production plant, perhaps in a different locality.

Celltech's need to produce larger quantities of protein grows at a rate that depends partly on how many contracts it wins, and partly on the speed with which its own products find a market. Confirming that it has decided to create its own business in biopharmaceuticals, including marketing and sales, Celltech's recently published 1987 Annual Report suggests two early products. One is a hybrid of an enzyme that dissolves blood clots and an antibody that delivers it to the clots; the other is 'calcitonin gene-related peptide', which may be used in the treatment of cerebrovascular problems. Peter Newmark 